\title{
UPAYA PENANGANAN KREDIT BERMASALAH PADA BANK NAGARI CABANG UTAMA PADANG
}

\author{
Winda Elo Mendari, Ratna Widayati \\ Akademi Keuangan dan Perbankan Padang \\ ratnawidayati@akbpstie.ac.id
}

\begin{abstract}
Bank as a financial institution serves as a financial intermediary or an intermediary of both parties namely the excess funds and parties lacking funds or parties who need funds. Any load disbursement by creditors or bank is a risk, because of he limitaions of human capability in predicting the future, therefore the bank mus plan in such a way and try to suppress the emergence of non performing credit risk. Non performing loans consist of special attention credits, non performing loans, doubt credit and bad debts, causes of non performing loans in the prsence of external factors where customers are unable to repay loans from banks. In the early stages of handling non performing loans is done byaproviding a warning letter in accordence with the level of credit problems but if when comes to letter of notification it will do draw collateral credit
\end{abstract}

Keyword: handling, non performing loans

\section{PENDAHULUAN}

Dalam perkembangan perekonomian lembaga keuangan sangat berperan penting dalam memenuhi kebutuhan perekomoni bagi masyarakat, karena lembaga keuangan merupakan bagian dari kebijakan pemerintah dalam memajukan perekonomian di Indonesia. Lembaga keuangan merupakan lembaga yang bertugas untuk menghimpun dana dari masyarakat dan menyalurkan kembali kepada masyarakat untuk memenuhi kebutuhan dana bagi pihak yang membutuhkan dana untuk kegiatan produktif maupun konsumtif.

Bank sebagai lembaga keuangan berfungsi sebagai financial intermediary atau perantara keuangan dari kedua pihak yakni pihak kelebihan dana dan pihak yang kekurangan.

Undang-Undang Republik Indonesia Nomor 101998 pasal 1 (2) menyatakan Bank adalah badan usaha yang menghimpun dana dari masyarakat dalam bentuk simpanan dan menyalurkannya kepada masyarakat dalam bentuk kredit dan atau bentuk-bentuk lainnya dalam rangka meningkatkan taraf hidup rakyat banyak.

Bank Nagari Cabang Utama Padang merupakan salah satu didaerah yang berperan penting dalam pertumbuhan ekomoni di Sumatera Barat. Keberadaan Bank Nagari Cabang Utama Padang sangat membantu dalam segala kegiatan perekonomian masyarakat maupun pemerintah daerah. Penyalurkan modal kepada masyarakat bertujuan untuk mendukung kegiatan ekonomi yang ada dimasyarakat, dengan tujuan untuk mempermudah para pengusah-pengusah dalam membangun perekonomian yang baik di Sumatera Barat. Diharapkan dengan 
pemberian modal ini pengusah-pengusaha dari berbagai sektor tersebut dapat menghasilkan barang dan jasa yang berkualitas. Penyaluaran modal tersebut di lakukan melalui pinjaman kredit.

Undang-Undang Republik Indonesia Nomor 10 tahun 1998 pasal 1 (11) menyatakan Kredit adalah penyediaan uang atau tagihan yang dapat dipersamakan dengan itu, berdasarkan persetujuan atau kesepakatan pinjam-meminjam antara bank dengan pihak lain yang mewajibkan pihak peminjam untuk melunasi utangnya setelah jangka waktu tertentu dengan pemberian bunga.

Padasetiap penyaluran kredit oleh bank tentu mengandung resiko, karena adanya keterbatasan kemampuan manusia dalam memprediksikan masa yang akan dating, oleh sebab itu bank harus merencanakan sedemikian rupa dan berusaha untuk menekan munculnya resiko kredit bermasalah. Oleh sebab itu bank harus mampu menilai kelayakan dari debitur serta perlu adanya pengelolaan dan pengawasan sehingga keseimbangan usaha bank terjaga.

Pada dasarnya pemberian kredit biasanya memliki konsep penilaian yang umum dan harus dilakukan oleh Bank Nagari Cabang Utama Padang untuk mendapatkan nasabah yang benar-benar layak untuk di berikan kredit yaitu dengan menganalisa calon nasabah. Menurut (Galih, 2009) konsep pemberian kredit 5C yaitu, Character (karakter), Capacity (kemampuan mengembalikan utang), Collateral (jaminan), Capital (modal), dan Condition (situasi dan kondisi). Hal ini dilakukan untuk memperkecil terjadinya kredit bermasalah pada Bank Nagari Cabang Utama Padang.

Kredit bermasalah tidak timbul ,adabeberapaaspek yang menyebabkan terjadinya kredit bermasalah antara lain dari pihak bank itu sendiri yang kurang teliti dalam menganalisa calon nasabah, kelengakapan dokumen dan adanya kolusi yang mengakibatkan adanya analisa yang dilakukan secara objektif, serta kredit masalah bisa terjadi karena pihak nasabah itu sendiri. Pada Bank Nagari Cabang Utama Padang faktor yang menyebabkan kredit bermasalah yaitu faktor internal dan eksternal. Faktor internal terjadi kerena ketidak telitian pihak bank pada saat menganalisa calon nasabah. Sedangkan faktor ekternal terjadi karena ketidak mampuan nasabah dalam membayar kembali dana yang telah di pinjam dan adanya ketidak inginan nasabah dalam membayar kembali kredit yang dipinjamnya meskipun nasabah tersebut memilki dana yang cukup.

Menurut (Rivai, 2013)pengertian kredit bemasalah merupakan kredit yang sejak jatuh tempo tidak dapat dilunasi oleh debitur sebagaimana mestinya sesuai dengan perjanjian.

Berdasarkan uraian diatas maka penulis tertarik membahasnya dalam tugas akhir yang berjudul "UpayaPenanganan Kredit Bermasalah Pada Bank Nagari Cabang Utama Padang"

Tujuan dari penelitian

a. Untuk mengetahui apa saja penyebab kredit bermasalah pada pada Bank Nagari Cabang Utama Padang.

b. Untuk mengetahui prosedur penanganan kredit bermasalah di pada Bank Nagari Cabang Utama Padang. 
ManfaatPenelitian

a. Bagi penulis sendiri berguna untuk menambah wawasan dan pengetahuan serta pengembangan ilmu pengetahuan yang penulis peroleh di bangku kuliah.

b. Bagi Bank Nagari Cabang Utama Padang manfaat penelitian ini yaitu untuk bahan informasi dan pertimbangan dalam kredit kepada para nasabah mengingat kredit mempunyai resiko yang sangat tinggi.

c. Bagi akademik untuk mengembangakan ilmu pengetahuan dan karya tentang upaya penanganan kredit bermasalah Bank Nagari Cabang Utama Padang.

\section{METODEPENELITIAN}

Dalam pengumpulan data dan bahan untuk melakukan penelitian ini di gunakan metode pengumpulan data sebagai berikut:

\section{Metode Pengumpulan Data}

a. Studikepustakaan (Library Reesearch)

Penelitian yang dilakukan dengan membaca karya ilmiah dan tulisantulisan yang berhubungan dengan objek penelitian dan pembahasan.

\section{b. Studi di lapangan (Field Research)}

Peninjauan langsung ke objek penelitian serta melakukan wawancara untuk mendapatkan data primer

\section{Metode Analisa Data}

Dalam menganalisa data, penulis mengunakan metode analisa kualitatif. Metode analisa data kualitatif ini digunakan sebagai metode penelitian yang memberikan gambaran umum tentang latar belakang penelitian dan sebagai bahan pembahasan hasil penelitian serta cendrung menggunakan analisis.

\section{ANALISA DAN PEMBAHASAN \\ Landasan Teori \\ Pengertian Bank}

Menurut Undang-Undang Republik Indonesia Nomor 10 tahun 1998 pasal 1 (2)Bank adalah badan usaha yang menghimpun dana dari masyarakat dalam bentuk simpanan dan menyalurkannya kepada masyarakat dalam bentuk kredit dan atau bentuk-bentuk lainnya dalam rangka meningkatkan taraf hidup rakyat banyak.

Sedangkan menurut para ahli (Rahmadhani \& Mawardi, 2011)Bank merupakan lembaga yang menghubungkan antara pihak yang kelebihandana dengan pihak yang kekurangan dana, dan memperlancar arus pembayaran, serta mencari keuntungan dari usaha yang dijalankannya.

Berdasarkan defenisi-defenisi tersebut dapat di simpulan bahwa fungsi bank ada dua yaitu sebagai penghimpun dana dari masyarakat dan menyalurkan dana kembali kemasyarakat melalui kredit.

\section{Fungsi bank}

(Konch, 2012) menyatakan bahwa Fungsi bank sebagai lembaga intermediasi khususnya dalam penyaluran kredit mempunyai peranan penting bagi pergerakan roda perekonomian secara keseluruhan dan memfasilitasi pertumbuhan ekonomi. Menurut (Rahmadhani \& Mawardi, 2011)secara umum fungsi utama bank adalah menghimpun danadari masyarakat dan menyalurkannya 
kembali pada masyarakat untuk berbagai tujuan atau sebagai financial intermediary. Secara lebih spesifik fungsi bank sebagai berikut:

a. Agent of Trust Dasar utama kegiatan perbankan adalah trust atau kepercayaan, baik dalam hal penghimpunan dana maupun penyaluran dana. Masyarakat akan mau menitipkan dananya di bank apabila dilandasi oleh unsur kepercayaan.

b. Agent of Development Tugas bank sebagai penghimpun dan penyaluran dana sangat diperlukan untuk kelancaran kegiatan perekonomian di sektor riil. Kegiatan bank tersebut memungkinkan masyarakat untuk melakukan investasi, distribusi, dan juga konsumsi barang dan jasa, mengingat semua kegiatan investasi-distribusi-konsumsi berkaitan dengan penggunaan uang.

c. Agent of Sevices Di samping melakukan kegiatan penghimpunan dan penyaluran dana, bank juga memberikan penawaran jasa-jasa perbankan yang lain kepada masyarakat. Jasa-jasa yang ditawarkan bank ini erat kaitannya dengan kegiatan perekonomian masyarakat secara umum.

Berdasarkan pendapat beberapa ahli tentang fungi bank dapat disimpulkan bahwa, fungsi bank berkaitan dengan pergerakan roda perekonomian masyarakat untuk melancarkan pembiayaan bagi pengusaha atau individu dalam melakukan kegiatan transaksi yang berhubungan dengan bank.

\section{Pengertian kredit}

Kata kredit berasal dari bahasa Romawi yaitu "credere" yang artinya percaya, kredit dapat diartikan juga sebagaipemberian prestasi (misalnya uang, barang) dengan balas prestasi (kontraprestasi) yang akan terjadi pada waktu yang akan datang( Dwi Riyadi, 2009).

(Undang-Undang Republik Indonesia Nomor 10, 1998)menyatakan bahwakredit adalah penyediaan uang atau tagihan yang dapat dipersamakan dengan itu, berdasarkan persetujuan atau kesepakatan pinjam-meminjam antara bank dengan pihak lain yang mewajibkan pihak peminjam untuk melunasi utangnya setelah jangka waktu tertentu dengan pemberian bunga.

Pemberian kredit dilakukan untuk meningkatkan tarap hidup masyarakat melalui pinjaman dana atau pemberian investasi berupa barang atau uang yang dapat di gunakan dan kermudian dikembalikan dalam jangka waktu yang telah di tentukan sesuai perjanjian pada awal pemberian kredit.

\section{Jenis-Jenis Kredit}

Didalam undang-undang tidak di jelaskan secara rinci tentang jenis-jenis kredit. menurut (Aman, 2009) jenis- jenis kredit sebagai berikut:

a. Kredit menurut sifat penggunaannya

Kredit ini digunakan Kreditur untuk keperluan sebagai berikut:

1) Kredit konsumtif Adalah

Kredit konsumtif Adalah fasilitas kredit yang diberikan bank kepada debitor untuk keperluan pembelian barang-barang konsumsi yang diperlukan debitor.

2) Kredit Produktif

Kredit yang ditujukan untuk keperluan produksi dalam arti luas. Melalui kredit produktif, utility uang dan barang akan bertambah meningkat. 
b. Kredit menurut keperluannya

Kredit menurut keperluannya dapat di bedakan sebagai berikut:

1) Kredit investasi

Kredit ini diberikan untuk keperluan penanaman modal.Kredit ini tidak dimaksudkan untuk pertambahan barang, modal serta fasilitasfasilitas lainnya yang berhubungan erat dengan hal itu.Misalnya untuk membangun pabrik, gudang, membeli atau mengganti mesinmesin dan lain-lain.

2) Kredit eksploitasi

Kredit eksploitasi adalah kredit yang diberikan kepada para nasabah untuk keperluan menutup biaya eksploitasi perusahaan secara luas baik berupa pembelian bahan-bahan baku,bahan-bahan penolong, maupun biaya produksi lainnya. Kredit eksploitasi dan investasi pada dasarnya dimaksudkan untuk meningkatkan produktivitas baik secara kualitatif maupun kuantitatif.

3) Kredit Perdagangan

Kredit perdagangan ini dipergunakan untuk keperluan perdagangan pada umumnya.Dengan kredit ini dapat dilakukan pemindahan barang dari suatu tempat ke tempat lainnya, sehingga dapat membawa peningkatan utility of place dari barang-barang yang bersangkutan.

c. Kredit menurut jangka waktu

1) Kredit jangka pendek, jangka waktu selama-lamanya satu tahun

2) Kredit jangka menengah adalah kredit yang berjangka waktu satu sampai dengan tiga tahun

3) Kredit jangka panjang,

kredit jangka panjangyaitu kredit yang berjangka waktu lebih dari tiga tahun.

d. Kredit menurut cara pemakaiannya

Kredit ini dapat digolongkan menjadi :

1) Kredit dengan uang muka

Pada kredit uang muka ini, penarikan kredit dilakukan sekaligus dalam arti kata maksimum kredit pada waktu penarikan pertama sepenuhnya.

2) Kredit rekening koran

Dalam sistem ini debitor menerima seluruh kreditnya dalam bentuk rekening koran dan kepadanya diberikan blangko cek. Nasabah bebas melakukan penarikan-penarikan kreditnya sesuai dengan yang dibutuhkan untuk usahanya sampai batas maksimum kredit yang ditetapkan, sedang rekening koran pinjamannya diisi menurut besarnya kredit yang ditarik. Penarikan yang telah melebihi batas maksimum telah ditetapkan tidak dikabulkan.

e. Kredit menurut jaminannya

1) Kredit tanpa jaminan

Kredit ini diberikan kepada nasabah tanpa adanya jaminan.Kredit tanpa jaminan ini disebut juga kredit blangko. Dalam dunia perbankan di Indonesia, jenis ini tidak lazim dipergunakan karena mengandung resiko yang besar bagi bank. 
2) Kredit dengan jaminan

Kredit ini diberikan kepada setiap nasabah (debitor) yang sanggup menyediakan suatu benda tertentu atau surat berharga atau orang diikat sebagai jaminan.

Sedangkan menurut(Rivai, 2013) kredit di bedakan sebagai berikut:

a. Kredit Modal Kerja

Kredit ini merupakan kredit yang diberikan untuk memenuhimodal kerja baik pengusaha kecil secara perorangan dan kelompok, maupun pengusaha besar perorangan dan berkelompok, pengajuan kredit ini misalnya untuk pembelian bahan baku ,bahan penolong, pembayaran tenaga kerja, pembelian barang dagang dan pengembangan usaha-usaha serta kepentingan lainnya.

b. Kredit Konsumtif

Kredit konsumtif merupakan kredit yang diberikan bank yangbersifat untuk keperluan bagi Pegawai, PNS dan Karyawan yang membutuhkan dana dalam pembelian peralatan rumah tangga, pendidikan, pernikahan maupun pengembangan usaha dan lain-lain.

\section{Pengertian Kredit Bermasalah}

Dalam pemberian kredit terdapt berbagai resiko termasuk terjadinya kredit yang menyebabkan terjadinya kesenjangan pada proses kegiatan bank yang bersangkutan,kredit bermasalah ini terjadi kerena adanya kredit yang ditidak tertagih yang menimbulkan kerugian terhadap bank. Menurut (Rivai, 2013)pengertian kredit bemasalah adalah kredit yang sejak jatuh tempo tidak dapat dilunasi oleh debitur sebagaimana mestinya sesuai dengan perjanjian.

Sedangkan menurut(Ambarsita, 2013) kredit bermasalah suatu keadaan dimana nasabah sudah tidaksanggup membayar sebagian atau seluruh kewajibannya kepada bank seperti yang telah diperjanjikan.

\section{Penyebab Kredit Bermasalah}

Kredit bermasalah mengambarkan terjadi kegagalan dalam menangani resiko yang biasanya cendrung terjadi dan menyebabkan kerugian yang dialami oleh pihak bank. Kredit bermasalah akan menjadi dampak buruk apa bila tidak di tangani dengan baik, kerena kredit merupakan salah satu kegiatan utama bank dan merupakan penghasil keuntungan bagi bank, maka dari itu bank harus menangani kredit bermasalah dengan mengetahui penyebab utama terjadi kredit bermasalah. Adapun terjadinya kredit bermasalah menurut (Rivai, 2013)

a. Kesalahan bank yang kurang teliti dalam pengecekan terhadap latar belakang calon nasabah, kurang tajam dalam menganalisis terhadap maksud dan tujuan penggunaan kredit dan sumber-sumber pembayaran kembali, tidak ada pemahaman terhadap kebutuhan keuangan yang sebenarnya dari calon nasabah. Tidak adanya ketelitian dalam menganalisis laporan keuangan calon nasabah kelengkap syarat-syarat yang dicantumkan.

b. Kesalahan nasabah ketidak kompeten nasabah, nasabah yang diberikan kredit tidak atau kurang pengalaman dalam urusan kredit yang menyebabkan nasabah kurang mengerti dengan syarat-syarat yang telah adi berikan.

c. Kredit bermasalah bisa disebabkan oleh faktor eksternal yaitu sebagai perubahan-perubahan political dan legal environment, deregulasi sektor 
real, financial dan ekonomi menimbulkan pengaruh yang merugikan seorang debitur. Perubahan tersebut merupakan tantangan terus-menerus yang dihadapi oleh pemilik dan pengelola perusahaan. Satu kunci menuju pengelolaan sukses dari suatu usaha aadalah kemampuan mengantisipasi perubahan dan cukup fleksibel dalam mengelola usahanya. Sebagai akibat gagalnya pengelola dengan tepat mengantisipasi dan menyesuaikan diri dengan perubahan tersebut, seperti:Kondisi perekonomian Perubahan-perubahan peraturan Bencana alam.

Sedangkan menurut (Sunindyo dan Wijayanti, 2010) kredit bermasalah di sebabkan oleh:

a. Adanya kelemahan sisi intern dari pihak debitur yang disebabkan oleh tidak ada itikad baik dari debitur, menurunnya usaha yang dilakukan oleh debitur untuk melakukan pembayaran angsuran, dan tidak adanya kejujuran dari debitur dalam penggunaan dana kredit yang awalnya sebagai biaya produksi menjadi biaya komsumtif.

b. Kelemahan sisi intern dari pihak bank yang disebabkan oleh tidak adanya itikad baik dari pihak bank yang mementingkan untuk kepentingnya pribadi, kurangnya kemampuan petugas bank dalam pengelolaan pemberian kredit mulai dari pengajuan sampai pencairan kredit.

c. Kelemahan dari pihak ekstren yang disebabakan terjadinya bencana alam yang tak terduga menyebabkan terjadinya kerugian serta adanya krisi moneter yang mengakibatkan terjadi inflasi yang mempengaruhi usaha debitur.

Identifikasi, TujuanPenanganan Kredit Bermasalah dan StrategiPenanganan Kredit Bermasalah

a. Identifikasi penanganan

Identifikasi penaganan kredit bermasalah dilakukann untuk mencapai sasaran dan tujuan dalam pengananan yang dilakukan bank dalam melakukan identifikasi dan analisa permasalahan kredit bermasalah. Pada dasarnya identifikasi penanangan kredit bermasalah dilakukan untuk menetapkan strategi dalam memperkecil kerugian bank harus fokus terhadap penilaian dari kemampuan nasabah dalam membayar kembali dana yang telah di pinjam, penilai ini juga di lakukan terhadap nilai agunan yang dijadikan sebagai agunan. Bank harus melihat kredibilitas dari debitur dengan melakukan identifikasi terhadap permasalahan yang di alami oleh dibitur yang mengakibatkan terjadi kredit bermasalah, Serta melakukan analisa untuk menentukan sejauh mana kerugian yang telah di sebabkan.

b. Tujuan Penanganan Kredit Bermasalah

Penanganan kredit bermasalah bertujuan untuk tetap mempertahan kondisi bank yang stabil sesuia dengan bussinessplan bank dan/atau peraturan bank. Tujuan penanganan kredit bermasalah ini juga untuk meningakatkan kesehatan bank, tujuan penangan kredit bermasalah ini dilakukan oleh Bank Nagari Cabang Utama Padang bertujuan agar bank tetap pada keadaan yang seimbang dan bank juga bisa mendapatkan dananya kembali sekaligus bisa meningakatkan pendapatan bagi bank. 
c. Strategi Penanganan kredit bermasalah

Strategi penanganan dilakukan untuk menentukan keberhasilan dalam penanganan kredit bermasalah, sehingga kerugian yang di sebabkan dapat ditekan seminimal mungkin. Strategi ini dilakukan dengan cara penilaian terhadap kemapuan debitur dalam membayar agunan, menetukan sasaran dalam memperkuat tingkat resiko yang tidak terlalu tinggi. Apabila terjadi kelemahan terhadap nilai agunan maka dapat dilakukan penambahan nilai oleh debitur, namun jika kredibilitas menajemen debitur melemah maka dapat dilakukan pembinaan dan penggantian menajemen.

\section{ANALISA DAN PEMBAHASAN \\ Prosedur Pemberian Kredit Pada Bank Nagari Cabang Utama Padang}

Prosedur pemberian kredit pada Bank Nagari Cabang Utama Padang sebagai berikut:

\section{Tahap Awal Pemberian}

a) Pengajuan permohonan kredit

Pengajuan ini dilakukan secara tertulis dengan mengisi formulir yang di sediakan oleh pertugas kredit.

b) Melengkapi dokumen identintas sebagai berikut

1) Foto copy KTP, SIM atau paspor

2) Foto copy akta nikah ( bagi yang sudah menikah)

3) Foto copy kartu keluarga

4) Foto copy buku tabungan dan membawa buku tabungan, apabila tidak memiliki nasabah wajib membuat buku tabungan baru.

\section{Tahap Penilaian dan Analisa}

Tahap penilaian ini harus memuhi syarat $5 \mathrm{C}$ yaitu

a) Character ( watak/kepribadian)

Penilaian karakter di lakukan dengan melakukan wawancara langsung ke calon debitur pada saat pengajuan pemohonan kredit hal ini dilakukan untuk melihat karakter yang dimilik oleh calon nasabah.

b) Capacity ( kemampuan)

Penilaian kemampuan nasabah dilihat dari kesanggupan pemohon dalam melunasi kewajibannya dengan cara melihat secara langsung kegiatan usaha yang akan diberikan kredit

c) Capital ( modal)

Penilaian ini dilakukan dengan cara melihat modal awal yang di miliki oleh calon debitur, hal ini dilakukan pihak bank agar dapat mempertimbangan dana yang akan mereka berikan kepada calon debitur.

d) Collateral ( jaminan)

Penilain terhadap jaminan bertujuan untuk menentukan nilai yang dimiliki oleh jaminan tersebut lebih besar atau kecil dari kredit yang akan dicarikan .

e) Condition Of Economi ( kondisi ekonomi)

Penilai terhadap kondisi ekonomi untuk melihat perngaruh yang akan di hadapi oleh calon debitur yang mengambil kredit di bank. 


\section{Tahap Rekomendasi}

Rekomendasi kredit merupakan usulan dan saran dari pejabat kredit atas suatu permohonan kredit yang didasari kesimpulan dari analisa yang telah dilakukan rekmendasi kredit dapat berupa usulan untuk di setujui atau di tolak.

\section{Tahap Keputusan}

Keputusan dilakukan oleh pejabat kredit yang berwewenang dalam pemberian keputusan, sedangkan keputusan diberikan secara tertulis dan ditanda tangani oleh pejabat yang berwewenang. Keputusan kredit biasanya diberikan dengan mempertimbangkan analisa kelayakan dan resiko.Pemberitahuan keputusana dilakukan secara tertulis dengan menggunakan surat ppemberitahuan persetujuan kredit dan di tanda tangani oleh pejabat kredit, surat pemberitahuan kredit biasanya dilengkapi dengan syarat- syarat yang ditetapkan oleh pihak bank. Apabila keputusan kredit di tolak oleh bank maka akan di sampaikan melalui surat penolakan dari bank.

\section{Tahap Realisasi Kredit}

Pada Bank Nagari Cabang Utama Padang realisasi kredit melalui rekening giro atau rekening tabungan nasabah, apabila nasabah tidak memiliki rekenig giro atau rekening tabungan di bank yang bersangkutan maka nasabah harus membuat rekening baru.

\section{Tahap Pengawasan Kredit}

Pengawasankredit merupakan kebijakan umum yang dilakuakn Bank Nagari yang harus di tempuhnya, kerena pengawasan kredit adalah fungsi manajemen dalam menjaga dan mengamankan kekayaan bank dalam bentuk perkreditan agar lebih efisien. Proses pengawasan kredit bisa dikatakan serangkai cara untuk mengidentifikasi, mengukur, memantau dan mengendalikan resiko yang di sebabkan oleh kredit bermasalah, hal ini dilakukan Bank Nagari Cabang UtamaPadang sebagai upaya mencegah terjadinya kredit bermasalah. Teknik yang dilakukan Bank Nagari Cabang Utama Padang dalam pengawasan kredit tidak hanya dibagian administrasi tetapi langsung meninjau ke lapangan.

Pengawasan ini dilakukan dari proses awal pemberian kredit, pencairan sampai tahap pelunasan, sehinnga proses pengawasan tersusun rapi sehingga terjadinya kredit bermasalah.

\section{Kredit Bermasalah}

Kredit bermasalah merupakan resiko yang sangat berpengaruh terhadap kelangsungan hidup suatu bank, karena apabila resiko ini tidak dapat teratasi dengan baik maka akan mengakibatkan terjadi ketidak seimbangan terhadap bank tersebut.

Kredit bermasalah di Bank Nagari Cabang Utama Padang dibagi berdasarkan penetapkan kualitas kredit sebagai berikut:

1. Kredit dalam perhatian khusus yaitu kredit yang terdapat tunggakan pembayaran pokok ataupun bunga yang melampui 90 hari dari waktu yang di sepakati

2. Kredit kurang lancar yaitu kredit yang terdapat tunggakan pembayaran pokok dan bunga melampui 120 hari dari waktu yang telah di sepakati.

3. Diragukan yaitu kredit yang terdapat tunggakan pembayaran pinjaman baik pokok dan atau bunga melampuai 180 hari yang telah di sepakati. 
4. Kredit macet yaitu kredit yang terdapat tunggakan pembayaran pokok ataupun bunga di atas 180 hari dari waktu yang telah di sepakati.

Tabel 1

Jumlahkeseluruhan kredit bermasalah dari tahun 2014 - 2017

(Dalam Bentuk Triliun)

\begin{tabular}{|c|c|c|c|}
\hline Tahun & $\begin{array}{c}\text { kredit yang di } \\
\text { cairkan }\end{array}$ & $\begin{array}{c}\text { Kredit yang } \\
\text { bermasalah }\end{array}$ & $\begin{array}{c}\text { Presentase kredit } \\
\text { bermasalah }\end{array}$ \\
\hline 2014 & 3.674 & 79,38 & $2,16 \%$ \\
\hline 2015 & 4.057 & 100,93 & $2,49 \%$ \\
\hline 2016 & 4.377 & 128.13 & $2,93 \%$ \\
\hline 2017 & 4.308 & 135,99 & $3,16 \%$ \\
\hline
\end{tabular}

Sumber. Laporan Bank Nagari

Dari tabel di atas dapat di simpulkan bahwa kredit bermasalah pada tahun 2014 lebih rendah kerana dari jumlah kredit yang dicarikan sebesar Rp 3.674 Triliun terdapat 2,16\% kredit bermasalah setara dengan $\mathrm{Rp} 79,38$ Triliun, pada tahun 2015 kredit yang dicairkan meningkat sebesar RP 4.057 Triliun dan terjadi peningkatan pada kredit bermasalah sebesar 2,49\% setara dengan Rp 100,93 Triliun sedangkan pada tahun 2016 tingkat pencairan kredit terus meningkat sebesar Rp 4.377 Triliun dengan jumlah kredit bermasalah sebesar 2,93\% setara dengan Rp 128,13 dan pada tahun 2017 tingkat pencairan kredit menurun dibandingkan tahun 2016 sebesar Rp 4.308 namun tingkat kredit bermasalah pada tahun 2017 lebih tinggi dari tahun sebelumnya yaitu 3,16\% setara dengan Rp 135,99 Triliun.

Kredit bermasalah ini disebabkan oleh faktor eksternal.

Upaya penanganan Kredit Bermasalah

Upaya penanganan kredit bermasalah pada Bank Nagari Cabang Utama Padang sebagai berikut:

1. Debitur dalam kategori kredit perhatian khusus, dilakukan melalui telpon atau sms, agar nasabah segera memenuhi kewajibannya supaya tidak terkena denda dan tidak membengkaknya hutang.

2. Debitur dalam kategorikredit kurang lancar, akan diberikan Surat Peringatan Pertama(SP 1) kepada debitur.

3. Debitur dalam kategori kredit diragukan, akan diberikan Surat Peringatan Kedua (SP II) kepada debitur.

4. Debitur dalam kategori kredit macet, akan diberikan Surat peringatan terakhir (SP III) kepada debitur.

5. Jika sampai dikeluarkannya SP III debitur tidak menanggapinya, maka pihak Bank akan melakukan menarikan barang agunan. Barang agunan yang ditarik akan dilelang untuk pelunasan hutang debitur dan biaya yang di tumbulkan. Apabila dana tersebut berlebih maka akan di kembalikan kepada debitur.

\section{SIMPULAN}

1. Kredit bermasalah pada Bank Nagari Cabang Utama Padang terdiri dari kredit butuh perhatian khusus, kredit kurang lancar, kredit di ragukan, dan kredit macet. Penyebab terjadinya kredit bermasalah pada Bank Nagari yaitu adanya faktor ekternal dimana nasabah tidak mampu membayar kembali pinjaman dari bank. 
2. penanganan kredit bermasalah dilakukan dengan cara memberikan surat peringatan sesuai dengan tingkat permasalahan kredit, denagn melakukan pendekatan kepada nasabah, surat peringatan pertama, surat peringatan ke dua sampai dengan Surat Pemberi tahuan ke III ( SP III). Apabila pihak nasabah tetap tidak membayar kewajibanya maka akan dilakukan penarikkan barang agunan kredit untuk dilakukan pelelangan. Dilelang untuk pelunasan hutang debitur dan biaya yang di timbulkan. Apabila dana tersebut berlebih maka akan dikembalikan kepada debitur

\section{DAFTAR PUSTAKA}

Alanshari, F., \& Marlius, D. (2018). Prosedur Pemberian Kredit KPR Pada PT. Bank Tabungan Negara (Persero) TBK Cabang Pembantu Bukittinggi. https://doi.org/10.31227/osf.io/rsfhc

Aman, E. P. T. (2009). manajemen pebankan. Manajemen Perbankan, 1, 47-48.

Ambarsita, L. (2013). Analisis penanganan kredit macet. Manajemen Bisnis, 3(1), $15-20$.

Amelia, L., \& Marlius, D. (2018). Pengendalian Kredit Dalam Upaya Menciptakan Bank Yang Sehat Pada PT. Bank Pembangunan Daerah Sumatera Barat Cabang Utama Padang. https://doi.org/10.31227/osf.io/kpc64

Andriani, B., \& Susanto, R. (2019). Pengawasan Kredit PT. Bank Perkreditan Rakyat (BPR) Ophir Pasaman Barat. https://doi.org/10.31219/osf.io/aunvc

Baiya, \& Fernos, J. (2019). Analisis Faktor-Faktor Penyebab Kredit Macet Pada Bank Nagari Cabang Siteba. https://doi.org/10.31227/osf.io/4xuks

Darmawanto, \& Fernos, J. (2019). Prosedur Pemberian Kredit Pada Bank Nagari Cabang Sijunjung. https://doi.org/10.31227/osf.io/psqfy

Firmansyah, A., \& Fernos, J. (2019). Analisis Kredit Bermasalah Dilihat Dari Standar Non Performing Loan (NPL) Pada PT. Bank Perkreditan Rakyat (BPR) Prima Mulia Anugrah Cabang Padang. https://doi.org/10.31227/osf.io/gcj94

Ikbal, M., \& Marlius, D. (2017). Pengaruh Jumlah Taksiran Dan Uang Pinjaman Terhadap Laba Bersih Pada PT. Pegadaian (UPC) Gurun Laweh. https://doi.org/10.31227/osf.io/uch4a

Konch. (2012). Perbankani Indonesia. Buletin Ekonomi Moneter Dan Perbankan, juli, 1-24.

Orlando, A., \& Susanto, R. (2019). Mekanisme Pencairan Kredit Usaha Rakyat Pada PT. Bank Rakyat Indonesia Unit Lubuk Buaya. https://doi.org/10.31219/osf.io/zuv2y 
Rahmadhani, L., \& Mawardi, W. (2011). Analisis Pengaruh CAR, Pertumbuhan DPK, Pertumbuhan Simpanan dari Bank Lain dan Suku Bunga SBI Terhadap Pertumbuhan Kredit, 1-25.

Rivai. (2013). Commercial Bank Management. Perbankan Dari Toeri Ke Praktik, 1 .

Riyadi, D. (2009). Tindakan Penyelamatan Dan Penyelesaian Kredit Bermasalah Di Pt. Bank Danamon Indonesia Tbk. Cabang Semarang Pemuda, 1, 1-133.

Shanjaya, A. R., \& Marlius, D. (2017). Peranan Laporan Keuangan Dalam Kebijaksanaan Pemberian Kredit Kepada Calon Nasabah Pada PT. BPR Batang Kapas. https://doi.org/10.31227/osf.io/uxmg6

Sunindyo Wijayanti. (2010). Faktor-Faktor Penyebab Kredit Bermasalah di PT.Bank Sulut Cabang Utama Manado. Jurnal EMBA, 1(4), 69-77.

Undang-Undang Republik Indonesia Nomor 10. (1998). Undang-Undang Republik Indonesia Nomor 10 Tahun 1998 Tentang Perubahan Atas Undang-Undang Nomor 7 Tahun 1992 Tentang Perbankan.1-29. 